\title{
PROYEK FIKTIF SEBAGAI MODUS KORUPSI DI RDONESIA
}

\author{
Rasina Padeni Nasution, M.H \\ Universitas Islam Negeri Sumatera Utara Medan \\ rasinasution@uinsu.ac.id
}

\begin{abstract}
A criminal act of corruption (Tipikor) is an act of enriching oneself or another person or a corporation by misusing the authority, opportunity or means available to it because of the position or status that can harm the state's finances or the state's economy. There are several modes of corruption, one of which is a fictitious project. This study aims to determine how fictitious projects become a mode of corruption in Indonesia. This study uses qualitative research with descriptive analysis method using secondary data sources, namely literature review. In contrast to general criminal cases, such as theft and fraud, corruption cases usually involve more than one person, such as excessive requests for pocket money and an increase in the frequency of official trips. Various forms of corruption are common among central and regional government agencies, BUMN and BUMD and in collaboration with third parties. Therefore, it can be concluded that fictitious projects are a mode of corruption in Indonesia in which many corruption cases occur with this mode.
\end{abstract}

Keywords: corruption, modes, projects, fictitious.

\section{A. Pendahuluan}

Calon pimpinan atau pemerintah atau Kepala Daerah dan anggota DPR RI yang diusung sebuah partai politik kerap kali dihubungkan dengan uang. Demikian juga setelah mendapatkan dan menduduki jabatan, para pimpinan ini dianggap akan cenderung melakukan perbuatan korupsi. Pimpinan pemerintah/Kepala Daerah dan anggota DPR RI yang sudah menduduki sebuah jabatan umumnya terlibat dalam berbagai kegiatan partai politik dan pembinaan wilayah pemilihannya berkaitan dengan uang. Demikian juga halnya dalam menduduki jabatan akan banyak terkait dengan proyek-proyek anggaran pemerintah. ${ }^{1}$

Permasalahan utama munculnya kasus korupsi adalah sebagai upaya untuk menggerakkan roda organisasi partai politik yang membutuhkan dana yang cukup besar. Dukungan dana selama ini secara resmi bersumber dari bantuan pemerintah untuk mendukung jalannya pembinaan partai politik, namun jumlahnya relatif kecil, bantuan para anggota dan atau sumbangan dalam bentuk dana bantuan dari perusahaan. Dana partai politik yang bersumber dari pemerintah, anggota partai politik dan sumbangan perusahaan hasilnya belum cukup untuk menjalankan roda keorganisasian

\footnotetext{
${ }^{1}$ Monang Siahaan, Pembaruan Hukum Pidana Indonesia (Jakarta: Grasindo, 2016), hal. 109.
} 
dan tidak sebanding dengan biaya operasional dalam menggerakan dan menjalankan partai politik maka untuk memenuhi kebutuhan tersebut solusi yang dipandang penting adalah dengan dilakukan korupsi untuk membiayai kegaitan partai politik. Upaya pengumpulan dana tersebut salah satunya dengan proyek-proyek yang masuk dalam pagu penyelanggaran pemerinah.

Proyek adalah suatu upaya seseorang atau beberapa orang, badan hukum atau bukan badan hukum untuk menyelenggarakan, mengupayakan sesuatu kegiatan atau pekerjaan yang selalu dimulai dengan perencanaan. Proyek memiliki makna yang sama dengan kegiatan, misalnya proyek sosial akan sama maknanya dengan kegiatan sosial. ${ }^{2}$

Kegiatan sendiri mengandung unsur-unsur yang lebih luas tetapi batasannya lebih singkat, yaitu suatu perbuatan yang dilakukan oleh seseorang atau lebih. Sedangkan yang dimaksud dengan proyek fiktif diartikan sebagai suatu perbuatan seseorang atau lebih dari satu orang pada sebuah badan hukum atau bukan badan hukkum, untuk menyelenggarakan atau mengupayakankan sesuatu kegiatan atau pekerjaan yang pengerjaannya dimulai dengan sebuah perencanaan, tetapi seluruhnya merupakan khayalan (fiktif) atau tidak pernah ada sama sekali. Perbuatan bertujuan untuk menguntungkan diri sendiri, kelompok, atau partai dengan menyalahgunakan kewenangan yang diamahkan. Perbuatan ini juga disebut dengan tindak pidana korupsi.

Tindak pidana korupsi disebut juga dengan extra ordinary crimes sehingga dibutuhkan penanggulangan atau upaya yang bersifat luar biasa (extra ordinary enforcement) dan tindakan-tindakan luar biasa pula (extra ordinary measures). Pada sistem ini, langkah komprehensif yang dapa dilakukan melalui Sistem Peradilan Pidana Indonesia (SPPI) yaitu dengan bagaimana merumuskan secara ideal dan dapat memformulasikan suatu sistem hukum pidana. ${ }^{3}$

Secara gradual Sistem Hukum Pidana Indonesia (SHPI) meliputi hukum pidana materiil dan hukum pidana formal. Hukum pidana materiil terdapat dalam KUHP maupun diluar KUHP. Kemudian hukum formal bersumber pada Undang-Undang Nomor 8 Tahun 1981 tentang Kitab Undang-Undang Hukum Acara Pidana (KUHAP). Oleh karena itu, tindak pidana umum dalam KUHP maupun tindak pidana khusus di luar KUHP sebagaimana halnya tindak pidana korupsi mengenal pidana dan pemidanaan. ${ }^{4}$ Pidana sendiri mempunyai karakteristik yang pada hakikatnya merupakan suatu pengenaan penderitaan atau nestapa atau akibat-akibat lain yang tidak menyenangkan yang diberikan dengan sengaja oleh orang atau badan yang mempunyai kekuasaan yang dikenakan kepada seseorang

2 TB Irman S, Anatomi Kejahatan Perbankan, (Bandung: MQS Piblishing, 2006), hal. 105.

${ }^{3}$ Ibid., hal. 8.

${ }^{4}$ Ibid., hal 9. 
atau Badan Hukum (korporasi) yang melakukan tindak pidana menurut undang-undang. ${ }^{5}$

\section{B. Metode Penelitian}

Pembahasan yang berhubungan dengan masalah yang telah dipaparkan sebelumnya tentunya harus menggunakan metodologi yang baik sehingga dapat menghasilkan solusi dan kesimpulan yang tepat sesuai dengan tujuan penelitian. Sebagaimana diketahui bahwa guna dari penelitian merupakan alat untuk memperoleh suatu pengetahuan tentang hal-hal yang diyakini secara keilmuan adalah benar dan teruji melalui berbagai proses baik dalam bertanya maupun dalam hal menjawab. ${ }^{6}$

Mengenai pembahasan ini dapat kita perhatikan bahwa metodologi yang tepat untuk dikembangkan adalah dengan pendekatan kualitatif, sehingga sesuai dengan prinsipnya ingin memberikan, menerangkan dan mendeskripsikan secara lugas dan kritis sehingga didapati makna dalam konteks yang sebenarnya. Upaya untuk memahami tentang proyek fiktif sebagai modus tindak pidana korupsi, perlu disusun secara sistematis dengan menggunakan metode penelitian yang terstuktur. ${ }^{7}$

Struktur penelitiannya harus dimulai dari menentukan alat pengumpul data sebagai instrumen yang digunakan dan jenis data yang dikumpulkan untuk dapat dianalisis. Analisis data akan menjawab rumusan masalah sebagai sebuah hasil penelitian yang dapat diukur dan diuji kebenarannya melalui jenis metode penelitian yang digunakan. Tujuan penulisan juga harus dapat dicapai, yang dalam penelitian ini adalah untuk mengetahui bagaimana proyek fiktif sebagai modus tindak pidana korupsi.

\section{Tindak Pidana Korupsi}

Tindak pidana korupsi merupakan salah satu bagian dari hukum pidana khusus. Apabila dijabarkan, tindak pidana korupsi mempunyai spesifikasi tertentu yang berbeda dengan hukum pidana umum, seperti penyimpangan hukum acara dan materi yang diatur dimaksudkan menekan seminimal mungkin terjadinya kebocoran serta penyimpangan terhadap keuangan dan perekonomian negara. ${ }^{8}$

Tindak pidana korupsi merupakan extra ordinary crimes sehingga diperlukan penanggulangan yang bersifat luar biasa (extra ordinary enforcement) dan tindakan-tindakan luar biasa pula (extra ordinary measures). Dari sistem ini, salah satu langkah komprehensif yang dilakukan

${ }^{5}$ Dwidja Priyatno, Sistem Pelaksanaan Pidana Penjara di Indonesiai, (Bandung: PT Rafika Aditama, 2013), hal. 7.

${ }^{6}$ M. Solly Lubis, Filsafat Ilmu dan Penelitian, (Bandung: Mandar Maju, 1994), hal. 80.

${ }^{7}$ Syamsul Arifin, Metode Penulisan Karya Ilmiah dan Penelitian Hukum, (Medan: Area University Press, 2012), hal 73.

${ }^{8}$ Ibid., hal. 2-3. 
Sistem Peradilan Pidana Indonesia (SPPI) adalah bagaimana secara ideal dapat memformulasikan suatu sistem hukum pidana. ${ }^{9}$

Korupsi sebagai bentuk kejahatan luar biasa (extra ordenary crime) telah merasuk kedalam lingkungan instansi pemerintahan, hampir disemua instansi pemerintahan tidak terlepas dari praktik korupsi. Praktik korupsi yang terjadi di Instansi pemerintahan tersebut jika di biarkan maka akan dapat mengangu kelangsungan bangsa Indonesia. Upaya pemberantasan korupsi telah dilakukan oleh pemerintah melalui institusi penegak hukumnya, mulai dari Kepolisian, Kejaksaan, dan Hakim. Polisi, Jaksa dan Hakim merupakan tiga unsur penting dalam penegak hukum yang masingmasing mempunyai tugas, wewenang dan kewajiban yang sesuai dengan Peraturan Perundang-Undangan yang berlaku. Namun upaya pemberantasan korupsi oleh lembaga tersebut dinilai belum cukup ampuh untuk melakukan pemberantasan korupsi karena upaya pemberantasan oleh aparat tersebut dilakukan dengan menggunakan cara yang biasa saja sehingga pencapaiannya sangat jauh dari yang diharapkan atau dapat dikatakan diluar ekspektasi.

Tindak pidana korupsi bukan hanya masalah hukum tetapi telah menjadi persoalan ekonomi, budaya dan politik. Meningkatnya angka tindak pidana korupsi yang dilakukan pejabat negara, kepala daerah atau bahkan wakil rakyat telah membawa berbagai bencana, tidak saja terhadap kehidupan berbangsa dan bernegara pada umumnya, tetapi juga dapat mengakibatkan berbagai kelemahan dan keterpurukan pada kehidupan generasi yang akan datang. Berdasarkan hal tersebut dibutuhakan penegakan hukum yang konsisten, tegas dan tidak diskriminatif terhadap siapa saja yang dinyatakan sebagai koruptor. Penegakan hukum yang tegas, konsisten dan tidak diskriminatif menjadi tonggak yang sangat penting demi terwujudnya pilar-pilar keadilan dan kepastian hukum, keadilan hukum dan kemanfaatan hukum, yang akhirnya mendatangkan kemanfaatan untuk masyarakat berupa efek jera, hingga dapat mencegah seseorang untuk melakukan korupsi. Kemudian akan tumbuhnya kepercayaan masyarakat terhadap upaya penegakan hukum serta menguatnya dukungan masyarakat terhadap lembaga dan aparatur penegak hukum.

Menurut Burhan Ashofa, ${ }^{10}$ suatu konsep merupakan abstaksi mengenai suatu fenomena yang dirumuskan atas dasar generalisasi dari jumlah karakteristik kejadian-kejadian, keadaan, kelompok, atau individu tertentu. Konsepsi adalah salah satu bagian terpenting dari teori, peranan konsepsi dalam penelitian ini untuk menggabungkan teori dengan observasi, antara abstrak dan kenyataan. Konsep diartikan sebagai kata yang

\footnotetext{
${ }^{9}$ Ibid., hal. 8 .

${ }^{10}$ Burhan Ashofa, Metodelogi Penelitian Hukum, (Jakarta: Rineka Cipta, 1996), hal. 19.
} 
menyatukan abstraksi yang digeneralisasikan dalam hal-hal khusus yang disebut definisi operasional. ${ }^{11}$

Kerangka konsepsional mengungkapkan beberapa konsepsi atau pengertian yang dipergunakan sebagai dasar penelitian hukum. Landasan konsepsional dalam penelitian ini digunakan untuk memperoleh dasar konseptual, bertujuan untuk menghindari pemahaman dan penafsiran yang berbeda serta memberikan pedoman dan arahan yang sama, antara lain:

1. Tindak pidana korupsi adalah setiap orang yang melawan hukkum melakukan perbuatan memperkaya diri sendiri atau orang lain atau suatu korporasi yang dapat merugikan keuangan negara atau perekonomian negara. ${ }^{12}$

2. Proyek fiktif adalah suatu perbuatan seseorang atau beberapa orang, badan hukum atau bukan badan hukum untuk memalsukan mengerjakan, mengusahakan sesuatu kegiatan tau pekerjaan yang selalu dimulai dengan perencanaan.

Pasal 2 ayat (1) dan Pasal 3 Undang-Undang Nomor 31 Tahun 1999 tentang Pemberantasan Tindak Pidana Korupsi, menyatakan bahwa tindak pidana korupsi (selanjutnya disebut Tipikor) adalah suatu perbuatan memperkaya diri sendiri atau orang lain atau suatu korporasi dengan menyalahgunakan kewenangan, kesempatan atau sarana yang ada padanya karena jabatan atau kedudukan yang dapat merugikan keuangan negara atau perekonomian negara. Secara umum, pengertian tipikor adalah suatu perbuatan curang yang merugikan keuangan negara. Penyelewwengan atau penggelapan uang negara untuk kepentingan pribadi dan orang lain.

\section{Faktor Pemicu Tindak Pidana Korupsi}

Penyebab korupsi beragam-ragam dan saling terkait antara penyebab dan akibat yang bersatu dengan yang lain serta merupakan sebuah lingkaran setan yang sulit untuk dipisahkan satu dan lainnya dan sulit untuk dicari penyebab mana yang memicu terlebih dahulu. ${ }^{13}$ Penyebab korupsi diantaranya yaitu:

1. Keserakahan dan sifat tamak.

2. Sesama pegawai negeri/pejabat Negara memiliki ketimpangan penghasilan.

3. Gaya hidup konsumtif.

4. Penghasilan yang tidak mencukupi.

5. Minimnya keteladanan dari seorang pemimpin.

6. Kultur organisasi yang tidak benar.

7. Kurang memadainya Sistem akuntabilitas di instansi pemerintah.

${ }^{11}$ Sumadi Suryabrata, Metodelogi Penelitian, (Jakarta: Raja Grafindo Pesada, 1998), hal. 31.

12 Lihat Pasal 2 ayat (1) Undang-Undang Nomor 31 Tahun 1999 tentang Pemberantasan Tindak Pidana Korupsi.

${ }^{13}$ Surachmin dan Suhandi Cahaya, Strategi dan Teknik Korupsi, (Jakarta: Sinar Grafika, 2011), hal 91. 
8. Sistem pengendalian manajemen sangat lemah.

9. Manajemen cenderung menutupi korupsi di dalam organisasinya.

10. Nilai-nilai negatif yang hidup dan berkembang di masyarakat yang telah membudaya.

11. Apatisme dari masyarakat terhadap tindak pidana korupsi.

12. Degradasi moral.

13. Kehidupan yang hedonis. ${ }^{14}$

14. Modernisasi.

15. Ajaran-ajaran agama kurang diterapkan secara benar.

16. Lemahnya penegekan hukum yang memberikan kepastian dan perlindungan.

17. Sanksi yang tidak setimpal dengan perbuatan korupsi dan hasil korupsi.

18. Faktor politik.

19. Budaya organisasi pemerintah.

20. Lemahnya pendidikan agama, moral dan etika.

21. Good Governance tidak dijalankan dengan benar.

22. Faktor ekonomi.

23. Manajemen yang kurang baik dan tidak ada pengawasan yang efektif dan efesien.

24. Modernisasi yang menyebabkan pergeseran nilai-nilai kehidupan yang berkembang dalam masyarakat. ${ }^{15}$

\section{Ciri-Ciri Tindak Pidana Korupsi}

Kasus-kasus Tipikor umumnya melibatkan beberapa orang, lain halnya dengan kasus-kasus tindak pidana umum (misalnya pencurian dan penipuan), seperti permintaan uang saku yang berlebihan dan peningkatan frekuensi perjalan dinas. Umumnya, Tipikor dilalukan secara tertutup, rahasia, tersembunyi yang melibatkan berbagai elemen yang kewajiban dan memiliki keuntungan secara timbal balik. Kewajiban dan keuntungan tersebut tidak selalu berupa uang namun dapat digantikan sesuai kepentingan dan kebutuhan kelompok atau persenonal yang terlibat, misalnya janji menempatkan pada sebuah jabatan jika proyek tembus dan dana dapat dicairkan.

Mereka yang terlibat Tipikor biasanya menginginkan keputusan yang tegas dah mampu untuk mempengaruhi keputusan-keputusan itu. Mereka yang terlibat Tipikor umunyanya juga berusaha menyelubungi dan menutupi perbuatannya dengan berlindung di balik pembenaran hukum. ${ }^{16}$

\section{Bentuk-Bentuk Korupsi}

\footnotetext{
${ }^{14} \mathrm{Ibid}$.

${ }^{15}$ Aziz Syamsuddin, Loc. Cit.

${ }^{16}$ Ibid.
} 
Adapun bentuk-bentuk korupsi yang sudah lazim dilakukan di lingkungan instansi pemerintah pusat maupun daerah, BUMN dan BUMD serta bekerjasama dengan pihak ketiga antara lain sebagai berikut: ${ }^{17}$

a. Penyelundupan dan transaksi ilegal di luar negeri.

b. Menggelapkan dan memanipulasi barang milik lembaga, BUMN/BUMD, swastanisasi anggaran pemerintah.

c. Transaksi penerimaan pegawai dengan menggunakan transaksi pengadaan barang.

d. Jual beli jabatan, promosi nepotisme dan suap promosi.

e. Menggunakan uang yang tidak tepat, memalsukan dokumen dan menggelapkan uang, mengalirkan uang lembaga ke rekening pribadi, menggelapkan pajak, jual beli besaran pajak yang harus dikenali, dan menyalahgunakan keuangan.

f. Menipu dan mengecoh, member yang salah, mencurangi dan memperdaya seta memeras.

g. Mengabaikan keadilan, member kesaksian palsu menahan secara tidak sah dan menjebak.

h. Mencari-cari kesalahan orang yang tidak bersalah.

i. Jual beli tuntutan hukuman, vonis, dan surat keputusan.

j. Tidak menjalankan tugas, desersi.

k. Menyuap, menyogok, memeras, mengutip pungutan secara tidak sah dan meminta komisi.

1. Jual beli objek pemeriksaan, menjual temuan, memperhalus dan mengaburkan temuan.

m. Menggunakan informasi internal dan informasi rahasia untuk kepentingan pribadi dan memuat laporan palsu.

n. Menjual tanpa izin jabatan pemerintah, barang milik pemerintah dan surat izin pemerintah.

o. Manipulasi peraturan, meminjamkan uang Negara secara pribadi. ${ }^{18}$

p. Menghindari pajak, meraih laba secara berlebihan.

q. Menjual pengaruh, menawarkan jasa perantara, komplik kepentingan.

r. Menerima hadiah uang jasa, uang pelican dan hiburan, perjalanan yang tidak pada tempatnya.

s. Penempatan uang pemerintah kepada Bank tertentu yang berani memberikan bujed yang tidak sesuai yang sebenarnya.

t. Berhubungan dengan organisasi kejahatan, operasi pasar gelap.

u. Perkoncoan, menutupi kejahatan.

v. Memata-matai secara tidak sah, mennyalahgunakan telekomunikasi dan pos untuk kepentingan pribadi.

w. Menyalahgunakan stempel dan kertas surat kantor, rumah jabatan dan hak istimewa jabatan.

\footnotetext{
${ }^{17}$ Surachmin dan Suhandi Cahaya. Op.Cit., hal. 43.

${ }^{18}$ Ibid, hal. 44.
} 
x. Memperbesar pendapatan resmi dan illegal.

y. Pimpinan penyelenggara Negara yang meminta fasilitas yang berlebihan dan double atau triple. ${ }^{19}$

Paparan di atas juga dapat dikatakan sebagai sebuah modus dalam melakukan tindak pidana korupsi. Berbagai upaya dilakukan untuk mendapatkan keuntungan pribadi dengan merugikan negara, baik dari segi keuangan negara maupan dari segi kepentingan ekonomi negara.

\section{Pengaturan Hukum tentang Tindak Pidana Korupsi di Indonesia}

Pembentuk Undang-Undang dalam berbagai perundang-undangan menggunakan perkataan kata "tindak pidana" sebagai terjemahan dari "strafbaar feit"tanpa memberikan sesuatu penjelasan mengenai apa yang sebenarnya dimaksud dengan perkataan "tindak pidana"tersebut. Secara harfiah perkataan tindak pidana dapat diterjemahkan sebagai suatu kenyataan yang dapat di hukum. Akan tetapi, diketahui bahwa yang dapat dihukum sebenarnya adalah manusia sebagai pribadi dan bukan kenyataan, perbuatan, ataupun tindakan. ${ }^{20}$

Menurut Wirjono Prodjodikoro, dalam perundang-undangan formal Indonesia, istilah "perisitiwa pidana" pernah digunakan secara resmi. Secara substansif, pengertian dari istilah "peristiwa pidana" lebih menunjuk kepada suatu kejadian yang dapat ditimbulkan oleh perbuatan manusia maupun oleh gejala alam. ${ }^{21}$

Tindak pidana juga dapat diartikan sebagai suatu dasar yang pokok dalam menjatuhi pidana pada orang yang telah melakukan perbuatan pidana atas dasar pertanggung jawaban seseorang atas perbuatan yang telah dilakukannya. Namun, sebelum itu mengenai dilarang dan diancamnya suatu perbuatan mengenai perbuatannya sendiri berdasarkan asas legalitas yang menentukan bahwa tidak ada perbuatan yang dilarang dan diancam dengan pidana jika tidak ditentukan terlebih dahulu dalam perundangundangan (Nullum Delictum Nulla Poena Sine Praevia Lege Poenali). ${ }^{22}$

Berbagai peraturan yang mengatur mengenai Tindak Pidana Korupsi diantaranya yaitu, Undang-Undang Dasar Tahun 1945, Kitab Undang-Undang Hukum Pidana, Kitab Undang-Undang Hukum Acara Pidana maupun peraturan-peraturan lain yang berkaitan dengan kebijakan hukum pidana dalam peraturan perundang-undangan di Indonesia yaitu Undang-Undang Nomor 31 Tahun 1999 Tentang Pemberantasan Tindak Pidana Korupsi,

${ }^{19}$ Ibid.

${ }^{20}$ P.A.F. Lamintang, Dasar-Dasar Hukum Pidana Indonesia, (Bandung: PT Citra Aditya Bakti, 1997), hal. 181.

21 Wirjono Prodjodikoro, Asas-Asas Hukum Pidana di Indonesia, (Bandung: Refika Aditama, 2003), hal. 33.

${ }^{22}$ Ibid. 
Undang-Undang Nomor 20 Tahun 2002 Tentang Perubahan atas UndangUndang Nomor 31 Tahun 1999 Tentang Pemberantasan Tindak Pidana Korupsi, Undang-Undang Nomor 8 Tahun 2010 tentang Pencegahan dan Pemberantasan Tindak Pidana Pencucian Uang dan Undang-Undang Nomor 30 Tahun 2002 Tentang Komisi Pemberantasan Korupsi, Undang-Undang Nomor 28 Tahun 1999 Tentang Penyelenggaraan Negara yang Bersih dan Bebas dari Korupsi, Kolusi dan Nepotisme, Undang-Undang Repbulik Indonesia Nomor 15 Tahun 2002 Tentang Tindak Pidana Pencucian Uang, Undang-Undang RI Nomor 25 Tahun 2003 Tentang Perubahan Atas UndangUndang Repbulik Indonesia Nomor 15 Tahun 2002 Tentang Tindak Pidana Pencucian Uang, Undang-Undang Nomor 39 Tahun 1999 Tentang Hak Asasi Manusia, Universal Declaration of Human Right, International Covenant On Civil And Political Rights (ICCPR 1966), Undang-Undang Nomor 12 Tahun 2005 tentang Pengesahan International Covenant On Civil And Political Rights (Kovenan Internasional tentang Hak-Hak Sipil dan Politik), UndangUndang Nomor 7 Tahun 2006 tentang Pengesahan United Nations Convention Against Corruption, Keputusan DPR-RI Nomor 16/DPRRI/I/2004-2005 tanggal 29 September 2004 tentang Kode Etik DPR-RI.

\section{E. Proyek Fiktif Sebagai Modus Tindak Pidana Korupsi}

Komisi Pemberantasan Korupsi (KPK) menetapkan dua pejabat PT Waskita Karya (Persero) Tbk. sebagai tersangka korupsi 14 proyek infrastruktur fiktif, Senin (17/12/2018). Dua pejabat yang dimaksud adalah Kepala Divisi II PT Waskita Karya periode 2011-2013, Fathor Rachman, dan Kepala Bagian Keuangan dan Risiko Divisi II PT Waskita Karya periode 20102014, Yuly Ariandi Siregar. Dari penyelidikan KPK, kedua pegawai Badan Usaha Milik Negara (BUMN) ini diduga menunjuk beberapa perusahaan subkontraktor untuk mengerjakan sejumlah proyek yang sebenarnya sudah dikerjakan oleh perusahaan lain.

Selanjutnya, para tersangka berkerjasama dan terorganisir membuat seolah-olah pekerjaan tersebut dikerjakan oleh perusahaan subkontraktor. Dua tersangka kemudian mengatur, mengarahkan dan merekomendasikan supaya PT Waskita Karya tetap yang melakukan pembayaran ke perusahaan subkontraktor. Oleh subkontraktor, uang dari pembayaran itu dibagikan lagi kepada sejumlah pihak yang telah disepakati sebagai penerima bagian, termasuk kedua tersangka. Modus ini lazim dikenal dengan istilah"double budgeting". Sejauh ini sudah ada empat perusahaan subkontraktor yang teridentifikasi terlibat. ${ }^{23}$

Adapun ke-14 proyek yang diduga disubkontrakkan oleh tersangka adalah:

1. Proyek normalisasi Kali Bekasi Hilir, Bekasi, Jawa Barat

23 https://beritagar.id/artikel/berita/modus-pegawai-bumn-kutil-duit-14-proyeknasional 
2. Proyek Banjir Kanal Timur (BKT) Paket 22, Jakarta

3. Proyek Bandara Udara Kuala Namu, Sumatra Utara

4. Proyek Bendungan Jati Gede, Sumedang, Jawa Barat

5. Proyek normalisasi Kali Pesanggrahan Paket 1, Jakarta

6. Proyek PLTA Genyem, Papua

7. Proyek Tol Cinere-Jagorawi (Cijago) Seksi 1, Jawa Barat

8. Proyek Fly Over Tubagus Angke, Jakarta

9. Proyek Fly Over Merak-Balaraja, Banten

10. Proyek Jalan Layang Nontol Antasari Blok M (Paket Lapangan Mabak), Jakarta

11. Proyek Jakarta Outer Ring Road (ORR) seksi W1, Jakarta

12. Proyek Tol Nusa Dua-Ngurah Rai-Benoa Paket 2, Bali

13. Proyek Tol Nusa Dua-Ngurah Rai-Benoa, Paket 4, Bali

14. Proyek Jembatan Aji Tulur-Jejangkat, Kutai Barat, Kalimantan Timur

Tersangka bisa disangkakan dan didakwa melanggar Pasal 2 ayat (1) atau Pasal 3 Undang-Undang Nomor 31 Tahun 1999 yang telah diubah dengan UU Nomor 20 Tahun 2001 tentang Pemberantasan Tindak Pidana Korupsi (Tipikor) juncto Pasal 55 ayat (1) ke-1 jucto Pasal 65 ayat (1) KUHP.

Mantan Ketua Mahkamah Konstitusi (MK) Prof. Mahfud MD menyebut bahwa tindak pidana korupsi di sektor swasta mulai merajalela dan berkembang biak layaknya tumbuhan yang dipupuk dengan modusmodus baru dan diluar nalar berfikir orang pada umumnya. Praktik korupsi sektor swasta semakin berkembang lantaran modus-modus korupsi di masa depan semakin meningkat dengan dorongan kemajuan teknologi infomasi dan komunikasi yang memudahkan untuk mengakses berbagai informasi yang dibutuhkan demi melancar aksi korupsi yang dilakukan. Salah satu contoh terkait praktik tindak pidana korupsi sektor swasta di Indonesia adalah ketika pabrik obat memfasilitasi dokter tertentu agar menggunakan produknya dari pabrik tersebut.

Padahal, hal tersebut melanggar undang-undang persaingan usaha dan dinyatakan dalam memonopoli. Mahfud mengatakan bahwa regulasi untuk menjerat koruptor sektor swasta di Indonesia belum mendukung seperti negara-negara lain. Soal praktik memperdagangkan pengaruh (trading influence). Dalam hal ini, seseorang menggunakan pengaruh untuk mendapatkan sesuatu dari pengaruh jabatannya. ${ }^{24}$ Berdasarkan hal tersebut jika ditelaah, tindak pidana korupsi akan berkembang sesuai tuntutan jamannya dan menyesuaikan dengan perkembangan jaman bahkan cara berfikir para pelaku tersebut bisa dikatakan lebih maju dari pada para penegak hukum, sehingga dalam menjalankan aksinya para pelaku tipikor sulit sekali untuk dijaring atau dikenakan pidana.

Berikut adalah 18 modus operandi yang dirangkum KPK:

${ }^{24}$ https://kabar24.bisnis.com/read/20190227/16/894051/mahfud-md-sebut-banyakmodus-baru-kasus-korupsi-di-sektor-swasta 
1) Pengusaha menggunakan pengaruh pejabat pusat untuk "membujuk" Kepala Daerah/Pejabat Daeerah mengintervensi proses pengadaan dalam rangka memenangkan pengusaha, meninggikan harga atau nilai kontrak, dan pengusaha tersebut memberikan sejumlah uang kepada pejabat pusat maupun daerah.

2) Pengusaha mempengaruhi Kepala Daerah/Pejabat Daerah untuk mengintervensi proses pengadaan agar rekanan tertentu dimenangkan dalam tender atau ditunjuk langsung, dan harga barang/jasa dinaikkan (mark up), kemudian selisihnya dibagibagikan.

3) Panitia pengadaan membuat spesifikasi barang yang mengarah ke merk atau produk tertentu dalam rangka memenangkan rekanan tertentu dan melakukan mark up harga barang atau nilai kontrak.

4) Kepala Daerah/Pejabat Daerah memerintahkan bawahannya untuk mencairkan dan menggunakan dana/anggaran yang tidak sesuai dengan peruntukannya kemudian mempertanggungjawabkan pengeluaran dimaksud dengan menggunakan bukti-bukti yang tidak benar atau fiktif.

5) Kepala Daerah/Pejabat Daerah memerintahkan bawahannya menggunakan dana/uang daerah untuk kepentingan pribadi koleganya, atau untuk kepentingan pribadi kepala/pejabat daerah ybs, kemudian mempertanggungjawabkan pengeluaran-pengeluaran dimaksud dengan menggunakan bukti-bukti yang tidak benar, bahkan dengan menggunakan bukti-bukti yang kegiatannya fiktif.

6) Kepala Daerah menerbitkan peraturan daerah sebagai dasar pemberian upah pungut atau honor dengan menggunakan dasar peraturan perundang-undangan yang lebih tinggi yang tidak berlaku lagi.

7) Pengusaha, pejabat eksekutif, dan pejabat legislatif daerah bersepakat melakukan ruislag atas aset Pemda dan melakukan mark down atas aset Pemda serta mark up atas aset pengganti dari pengusaha/rekanan.

8) Para Kepala Daerah meminta uang jasa (dibayar dimuka) kepada pemenang tender sebelum melaksanakan proyek.

9) Kepala Daerah menerima sejumlah uang dari rekanan dengan menjanjikan akan diberikan proyek pengadaan.

10) Kepala Daerah membuka rekening atas nama kas daerah dengan specimen pribadi (bukan pejabat dan bendahara yang ditunjuk), dimaksudkan untuk mepermudah pencairan dana tanpa melalui prosedur.

11) Kepala Daerah meminta atau menerima jasa giro/tabungan dana pemerintah yang ditempatkan pada bank. 
12) Kepala Daerah memberikan izin pengelolaan sumber daya alam kepada perusahaan yang tidak memiiki kemampuan teknis dan finansial untuk kepentingan pribadi atau kelompoknya.

13) Kepala Daerah menerima uang/barang yang berhubungan dengan proses perijinan yang dikeluarkannya.

14) Kepala Daerah/keluarga/kelompoknya membeli lebih dulu barang dengan harga yang murah kemudian dijual kembali kepada instansinya dengan harga yang sudah di-mark up.

15) Kepala Daerah meminta bawahannya untuk mencicilkan barang pribadinya menggunakan anggaran daerahnya.

16) Kepala Daerah memberikan dana kepada pejabat tertentu dengan beban kepada anggaran dengan alasan pengurusan DAU/DAK.

17) Kepala Daerah memberikan dana kepada DPRD dalam proses penyusunan APBD.

18) Kepala Daerah mengeluarkan dana untuk perkara pribadi dengan beban anggaran daerah. ${ }^{25}$

Indonesia Corruption Watch mencatat, pada tahun 2017 terdapat 576 kasus korupsi dengan kerugian negara mencapai Rp 6,5 triliun dan suap Rp 211 miliar. Jumlah tersangkanya mencapai 1.298 orang. Berdasarkan rilis ICW, Selasa (20/2/2018), jika dibandingkan tahun 2016, penanganan kasus korupsi tahun 2017 mengalami peningkatan signifikan. Hal ini terutama pada aspek kerugian negara. Pada 2016, kerugian negara dari 482 kasus korupsi mencapai Rp 1,5 triliun. Angka ini naik menjadi Rp 6,5 triliun pada tahun 2017. Modus korupsi yang paling banyak digunakan dalam kasus korupsi tahun 2017 adalah penyalahgunaan anggaran. Ada 154 kasus dengan kerugian negara mencapai $\mathrm{Rp}$ 1,2 triliun dengan modus ini. Modus lainnya, penggelembungan harga (mark up) dan pungutan liar dengan masing-masing sebanyak 77 kasus dan 71 kasus. ${ }^{26}$

\section{Penutup}

Tindak pidana korupsi merupakan extra ordinary crimes sehingga diperlukan penanggulangan yang bersifat luar biasa (extra ordinary enforcement) dan tindakan-tindakan luar biasa pula (extra ordinary measures). tindak pidana korupsi di sektor swasta mulai merajalela dengan modus-modus baru. Praktik korupsi sektor swasta lantaran modus-modus korupsi di masa depan semakin berkembang. Salah satu contoh terkait praktik tindak pidana korupsi sektor swasta di Indonesia adalah ketika pabrik obat memfasilitasi dokter tertentu agar menggunakan produknya dari pabrik tersebut. Padahal, hal tersebut melanggar undang-

\footnotetext{
${ }^{25}$ https://nasional.kompas.com/read/2008/08/22/19465330/inilah.18.modus.opera ndi.korupsi.di.daerah?page $=$ all

${ }^{26}$ https://nasional.kompas.com/read/2018/02/20/07542211/tren-modus-korupsi2017-versi-icw page $=$ all
} 
undang persaingan usaha. Tindakan modus yang saat ini berkembang dengan adanya proyek fiktif. Memanfaatkan anggaran negara untuk kepentingan pribadi, kelompok dan partai politik.

\section{Daftar Pustaka}

Burhan Ashofa, 1996, Metodelogi Penelitian Hukum, Jakarta: Rineka Cipta.

Dwidja Priyanto, 2009, Sistem Pelaksanaan Pidana Penjara di Indonesia, Bandung: PT. Rafika Aditama.

Dwidja Priyatno, 2013, Sistem Pelaksanaan Pidana Penjara di Indonesiai, Bandung: PT Rafika Aditama.

Eva Achjani Zulfa, 2011, Pergeseran Paradigma Pemidanaan, Bandung: CV. Lubuk Agung.

Leden Marpaung, 2009, Asas-Teori-Praktek Hukum Pidana, Jakarta: Sinar Grafika.

Lexy J. Moloeng, 1993, Metodologi Penelitian Kualitatf, Bandung: PT Remaja Rokakarya.

M. Solly Lubis, 1994, Filsafat Ilmu dan Penelitian, Bandung: Mandar Maju.

M. Syukri Akub dan Baharuddin Baharu, 2012, Wawasan Due Proses Of Law dalam Sistem Peradilan Pidana, Yogyakarta: Mahakarya Rangkang Offset.

Monang Siahaan. 2016. Pembaruan Hukum Pidana Indonesia. Jakarta: Grasindo.

Mukti Fajar dan Yulianto Achmad, 2010, Dualisme Penelitian Hukum Normatif \& Empiris, Yogyakarta:Pustaka Pelajar.

Otje Salman \& Anthone F. Susanto, 2007, Teori Hukum, Bandung: Refika Aditama.

Syamsul Arifin, 2012, Metode Penulisan Karya Ilmiah dan Penelitian Hukum, Medan: Area University Press.

Soerjono Soekanto, 1986, Pengantar Penelitian Hukum, Jakarta: UI Press.

Sumadi Suryabrata, 1998, Metodelogi Penelitian, Jakarta: Raja Grafindo Pesada,.

Sunaryati Hartono, 1994, Penelitian Hukum Indonesia Pada Akhir Abad ke20, Bandung: Penerbit Alumni.

Soerjono Soekanto, 2008, Pengantar Penelitian Hukum, Jakarta: UII Press.

Surachmin dan Suhandi Cahaya. 2011. Strategi dan Teknik Korupsi. Jakarta: Sinar Grafika.

Teguh Prasetyo dan Abdul Halim Barkatullah, 2005, Politik Hukum Pidana (Kajian Kebijakan Kriminalisasi dan Dekriminalisasi), Jakarta: Pustaka Pelajar.

TB Irman S. 2006. Anatomi Kejahatan Perbankan. Bandung: MQS Piblishing. 